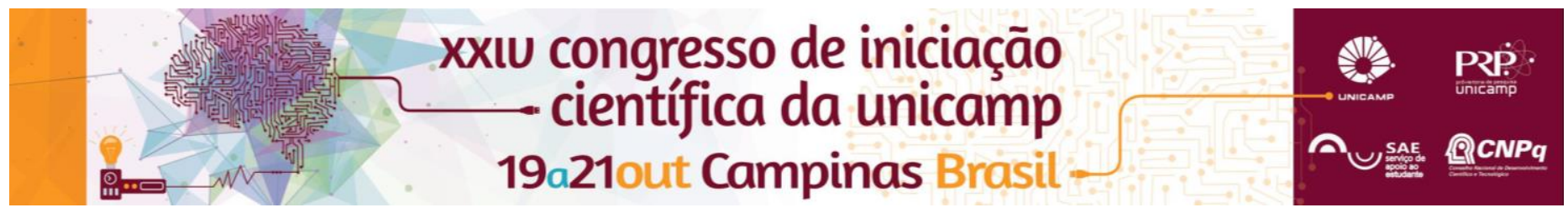

\title{
O PAPEL DA "GINASTRADA REGIONAL" PARA O DESENVOLVIMENTO DA GINÁSTICA GERAL PAULISTA: ANÁLISE E PROPOSTAS.
}

\author{
Renata A. Barbosa*, Eliana de Toledo.
}

\section{Resumo}

A Ginástica para Todos (GPT) anteriormente denominada Ginástica Geral é uma manifestação gímnica que está em plena ascensão no Brasil, desde a década de 90 (PAOLIELLO et al, 2014) em sua gênese não possui caráter competitivo, mas há eventos internacionais muito tradicionais como o Gym For Life - organizado pela FIG (http://www.fig-gymnastics.com/site/page/view?id=385) que estimulam essa possibilidade. Essa obra apresentada, tem como objetivo analisar todas as edições da "Ginastrada Regional", um evento de GPT com formato competitivo, que existe desde 1984 e já se reproduziu em 24 edições anuais, organizada pela Coordenadoria de Esporte do Estado de São Paulo. Há uma hipótese que esse evento tenha colaborado sobremaneira para a difusão da GPT no Estado de São Paulo (SP) e que tenha sido o primeiro e mais duradouro evento de GPT do Brasil até a atualidade.

Palavras-chave:

Ginástica Geral, Ginastica para Todos, Ginastrada Regional.

\section{Introdução}

A Ginastrada tem como objetivo oportunizar a pratica da GPT para grupos de diferentes manifestações gímnicas bem como a divulgação dos conhecimentos técnicos da área (regulamento técnico de 2005). Este evento atingiu atletas do Estado de SP e contava com grupos distintos, tanto em relação à categoria/faixa etária dos participantes quanto em relação à proposta de cada grupo (BARBOSA, 2014, p.268). A grande precursora desse evento foi a professora Glícia Maria Bellemo, que na época era Coordenadora de Esporte de SP, a última edição deste evento aconteceu no ano de 2013, e em seu ápice contou com 5 mil pessoas. Na década de 80 ainda não existia o comitê de GPT na CBG e na Federação Paulista, por isso a Ginastrada Regional pode ser considerada pioneira na difusão de GPT no estado de $\mathrm{SP}$.

\section{Resultados e Discussão}

Os documentos analisados foram separados em duas partes a primeira dando enfoque nos regulamentos e a segunda nos perfis do grupo. Na análise dos regulamentos foram utilizados os anos de 2005, 2006 e 2013 (regulamentos encontrados no acervo), o mesmo foi separado por itens:

\begin{tabular}{|l|l|}
\hline \multicolumn{2}{|c|}{ Regulamento } \\
\hline Objetivos & $\begin{array}{l}\text { Oportunizar a pratica gímnica a todos e divulgação de } \\
\text { conhecimentos técnicos }\end{array}$ \\
\hline Categorias & Infantil (até 12 Anos); Aberta (acima de 12 anos) \\
\hline Participação & Grupa A: Ginástica; Grupo B: Dança; Grupo C: Grandes Grupos. \\
\hline Inscrições & $\begin{array}{l}\text { Todos os inscritos na coreografia deverão participar } \\
\text { efetivamente. }\end{array}$ \\
\hline $\begin{array}{l}\text { Forma de } \\
\text { Realização }\end{array}$ & $\begin{array}{l}\text { Fase Regional (FR) separa por regiões administrativas e Fase } \\
\text { Final 3 primeiros colocados de cada FR. }\end{array}$ \\
\hline & $\begin{array}{l}\text { Atribuição de notas para: 1. Movimento e ritmo musical; 2. } \\
\text { Técnica Corporal; 3. Execução; 4. Expressão Corporal; 5. }\end{array}$ \\
Julgamento & $\begin{array}{l}\text { Coreografia; 6. Visual/originalidade; 7. Utilização do espaço; 8. } \\
\text { Conjunto; 9. Formação descritas do espaço. }\end{array}$ \\
\hline Premiação & Medalhas e Troféu \\
\hline $\begin{array}{l}\text { Disposições } \\
\text { Gerais. }\end{array}$ & $\begin{array}{l}\text { aparelhos usados, documentação necessária para participação, } \\
\text { patrocinadores, delegação, alojamento. }\end{array}$ \\
\hline
\end{tabular}

Tabela 1. Regulamento Ginastrada Regional.

$\mathrm{Na}$ análise dos grupos utilizamos as fichas de inscrições dos anos de 2005, 2006, 2007, 2012 e 2013 (fichas encontradas no acervo), nela continha a categoria e tipo de instituição que o grupo pertencia:

\begin{tabular}{|l|r|}
\hline \multicolumn{2}{|c|}{ Análise dos Grupos } \\
\hline \multicolumn{2}{|c|}{ Categorias } \\
\hline Infantil (até 12 anos) & 22 grupos inscritos \\
\hline Aberta (acima de 12 anos) & 46 grupos inscritos \\
\hline \multicolumn{2}{|c|}{ Perfil } \\
\hline Colégio & 2 \\
\hline Academia de Ballet & 2 \\
\hline Academia de Artes & 1 \\
\hline Academia Geral & 4 \\
\hline Academia de Dança & 25 \\
\hline Clube & 2 \\
\hline Escola & 7 \\
\hline Órgão Público & 33 \\
\hline Grupo & 1 \\
\hline Academia de Ginástica & 2 \\
\hline
\end{tabular}

Tabela 2. Fichas de inscrição Ginastrada Regional.

Em todos os anos analisados o objetivo do evento se manteve no sentido oportunizar a pratica da GPT, sendo atletas de alto rendimento ou praticantes de ginástica. Mesmo tendo o formato competitivo um público muito amplo foi atingido desde escolas ate academia de dança profissional.

\section{Conclusões}

O Festival Ginastrada Regional foi um grande disseminador da GPT no Estado de SP, mesmo com seu formato competitivo ele oportunizou a prática a muitas pessoas que não teriam essa chance no alto rendimento. No Brasil existe uma lacuna de pesquisa sobre a história da GPT. Este trabalho além de analisar a hipótese da Ginastrada Regional ter sido uma grande disseminadora no estado de SP, também faz uma pesquisa histórica a cerca deste tema

\section{Agradecimentos}

A colaboração da Prof, Glicia Maria Bellemo foi indispensável para a elaboração desta pesquisa.

PAOLIEllo, E; TOLEDO, E.; AYOUB, E.; BORTOLETO, M. A. C; GRANER, Larissa. Grupo Ginástico Unicamp: 25 anos. Campinas: Editora da Unicamp, 2014.

BARBOSA. R. A. - A vivência de duas concepções de Ginástica para todos: Um relato de experiência. UNICAMP/FCA: SESC, 2014. P. 268 Gym For Life, disponível em <http://www.gymforlife.co.za/about-us/aboutgym-for-life-world-challenge> acessado em: Março de 2015. 